\title{
Realist International Theory and the Military
}

\author{
Brian C Schmidt
}

\section{Contents}

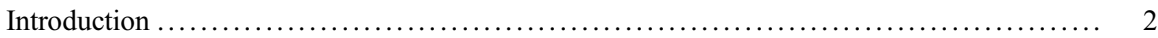

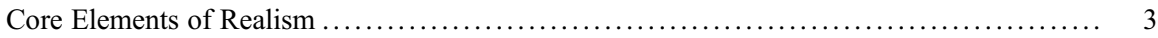

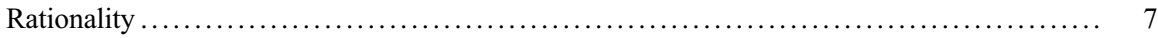

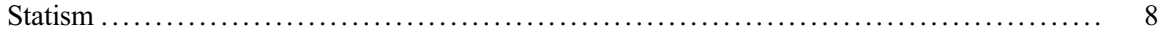

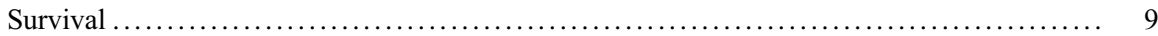

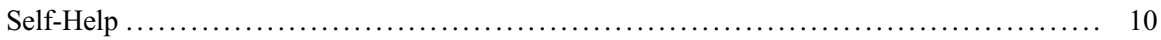

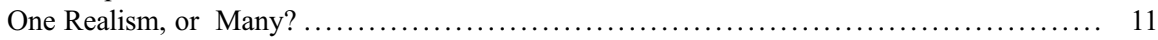

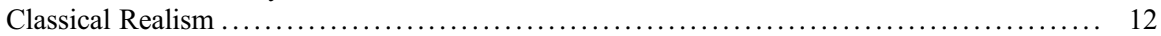

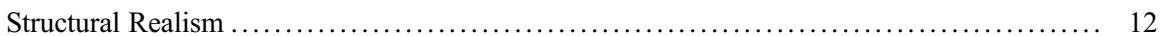

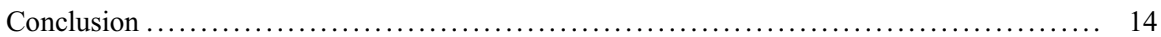

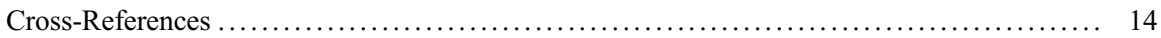

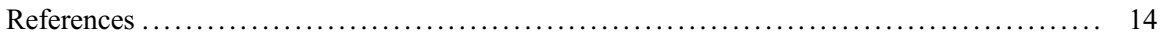

\section{Abstract}

Realism is generally seen as one of the most influential theories of international politics. Military and foreign policy officials adhere to the apparent timeless insights of realism. They stress the importance of power, especially military power, and the need to ensure the survival and security of the state. Ontologically, realism depicts a hostile world of power-seeking states. Some realists explain this in terms of human nature while others emphasize the anarchical structure of international politics. The chapter begins with a brief overview of the development of realist theory from Thucydides, who was an Athenian military official, to the present day. The next section explains the various epistemological, methodological, and ontological positions that realists hold. Next, the common elements that comprise the essence of realism will be identified: rationality, statism, survival, and self-help (the three S's). In the third section, the differences between two variants of realist theory, classical and structural realism, are explained. In the

B. C. Schmidt $(\triangle)$

Department of Political Science, Carleton University, Ottawa, ON, Canada

e-mail: BrianSchmidt@Cunet.Carleton.Ca 
conclusion the timeless wisdom of realism is revisited by considering the rise of China and the implications this has for international order.

\section{Keywords}

Classical realism $\cdot$ Structural realism $\cdot$ Power $\cdot$ Balance of power $\cdot$ Anarchy $\cdot$ security $\cdot$ Self-help $\cdot$ Survival $\cdot$ Rationality

\section{Introduction}

The political scientist Robert Gilpin (1996) once wrote that "no one loves a political realist." One way to interpret Gilpin's sentiment is that realists frequently present a pessimistic and tragic view of international politics. No matter the proposal, realists recognize that there are enduring patterns of behavior that frequently thwart the noblest of intentions to reform the practice of international politics. Realists concede that peace is a worthwhile goal but at the same recognize that it is frequently illusive. Rather than striving for perpetual peace, which is impossible, realists seek to reduce the incidence of war and the recourse to violence. In the process, they offer a set of prescriptive maxims to guide state behavior. While many have sought to wish away or dismiss the principles of realism, realists throughout the ages retort that when ignored, bad things often follow.

Part of the appeal of realism is the claim that it provides timeless insights about the practice of international politics. The idea of the timeless wisdom of realism rests, in part, on the claim that contemporary realists are part of an ancient and continuous tradition of thought that goes all the way back to the writings of Thucydides (460-406 BC) and his account of the Peloponnesian War. This is perhaps best illustrated by the notion that today the United States and China are looked in a "Thucydides trap," which is analogous to the situation faced by Athens and Sparta (Allison 2018). The academic theory of Realism that became dominant after World War Two is often claimed to rest on an older, classical tradition of thought. Although there are various criteria of what constitutes a tradition, common to most understandings is the idea that a similar set of ideas, customs and practices are handed down from one generation to the next. The belief that there is a realist tradition of thought rests on the claim that there are a set of assumptions and ideas that all realists embrace. Yet while it is demonstrated that most realists do subscribe to a shared set of assumptions including rationality, statism, survival, and self-help (the three Ss'), it is also argued that there are a number of distinct realist theories such as classical, structural, and offensive realism. The diversity of realisms makes it difficult to establish a unified realist ontology, epistemology, and methodology. Additionally, even philosophers of science disagree about the meaning of these terms. To simplify greatly, ontology deals with the question of what exists and constitutes reality, epistemology is concerned with the question of what constitutes knowledge, and methodology addresses the issue of how knowledge is generated (for further elaboration, see this handbook's first section). 
The chapter begins with a general introduction to the so-called realist tradition. Here some attention is devoted to the writers and ideas that predated realism as a formal theory of international politics. The main focus of this section, however, will be on the development of realist theory beginning in the late 1940s. In the next section, the key assumptions of what can be termed the essential realism are identified and explained. In the third section, several distinct realist theories are specified, including classical, structural, and offensive realism. In the concluding section, the idea of the timeless wisdom of realism and its applicability to the present age is discussed again.

\section{Core Elements of Realism}

According to the conventional wisdom, during the 1940s realism replaced idealism as the dominant theory of international politics. Writing in the aftermath of the First World War, the "idealists," a term that realist writers have retrospectively imposed on the inter-war scholars, focused much of their attention on understanding the cause of war so that a remedy could be found. Yet the post-World War Two realists argued that the inter-war scholars' approach was flawed in a number of respects. For example, they ignored the role of power, overestimated the degree to which states shared a set of common interests, and were overly optimistic that the League of Nations could overcome the scourge of war. The outbreak of the Second World War in 1939 confirmed, for the realists at least, the inadequacies of the idealists' approach to studying international politics.

A new approach, one based on the timeless insights of realism, replaced the discredited idealist approach. Writing on the eve of World War Two, E.H. Carr, in his brilliant book The Twenty Years' Crisis (1939), charged that International Relations (IR) had been in an initial phase of wishful thinking and argued that a new phase of realism was needed in order to advance a science of international politics. However, it was not exactly clear what Carr meant by either science or realism. Histories of the academic field of IR describe a Great Debate that took place in the late 1930s and early 1940s between the inter-war idealists and a new generation of realists who all emphasized the ubiquity of power in the politics among nations (Schmidt 2012). The standard account of the Great Debate is that the realists emerged victorious, and from 1939 to the present, theorists, policy-makers, and military officials have continued to view the world through a realist lens. Realism taught foreign policy officials to focus on interests rather than on ideology, to seek peace through strength, and to recognize that great powers can coexist even if they have antithetical values and beliefs. The fact that realism offers something of a manual for maximizing the interests of the state in a hostile environment explains why it remains the dominant tradition in the study of world politics.

The theory of realism that prevailed after the Second World War is often claimed to rest on an older, classical tradition of thought. It is not uncommon for contemporary realist writers to claim themselves to be part of an ancient tradition of thought that includes such illustrious figures as Thucydides (c. 460-406 BC), Niccolò 
Machiavelli (1469-1527), Thomas Hobbes (1588-1679), Jean-Jacques Rousseau (1712-78) and a variety of other thinkers and practitioners such as Otto von Bismarck. The insights that these thinkers offered into the way in which state leaders should conduct themselves in the realm of international politics are often grouped under the doctrine of raison d'état, or reason of state. According to the historian Friedrich Meinecke, raison d'état is the fundamental principle of international conduct, the state's First Law of Motion: "It tells the statesman what he must do to preserve the health and strength of the State" (1957, p. 1). Most importantly, the state, which is identified as the key actor in international politics, must pursue power, and it is the duty of the statesperson to calculate rationally the most appropriate steps that should be taken to perpetuate the life of the state in a hostile and threatening environment. Here the contours of the realist ontology of international politics are seen as a realm of competition and security seeking behavior. Ontology in this sense is literally an account of the nature of "reality"; that is, of what exists. The survival of the state can never be guaranteed, because the use of force culminating in war is a legitimate instrument of statecraft. This leads to the realist maxim, which is sometimes understood in terms of Realpolitik, that "the law of the strong is the determining factor in politics" (Bew 2016, p. 32). For many, this insight originates with Thucydides' account of the Melian dialogue where the Athenians announce that they are following the timeless principle that the powerful do what they want and the weak have to endure the consequences. In this particular dialogue between a powerful Athens that is intent on conquest and the weak island of Melos that is seeking survival, Thucydides seeks to demonstrate that the desire for power and the need to follow self-interest are fundamental laws of nature.

Hobbes is another political theorist that realists often rely on to support their ontology of international politics as a never-ending struggle for power. Hobbes provided the first English translation of Thucydides' History of the Peloponnesian War. What intrigues realists about Hobbes is his account of the state of nature, which is envisioned as a time before people lived under the rule of a powerful centralized government. This situation is seen as analogous to the anarchical condition of international politics where there is no higher authority above the collection of sovereign states. Anarchy in this sense refers to a condition where there is no higher authority to make laws. For Hobbes, in the absence of an overarching power, human beings exhibited "a perpetuall and restlesse desire of Power after power, that ceaseth onely in Death" (1968, p. 161). Moreover, he claimed that life in the state of nature was "solitary, poore, nasty, brutish, and short" (1968, p. 161). In this anarchical situation, the only solution, according to Hobbes, was to form a social contract and establish a centralized authority to help keep law and order. However, in solving the problem of disorder domestically by creating a sovereign authority, the same set of characteristics that Hobbes associated with the state of nature are transferred to the realm of international politics where no higher authority exists. In fact, Hobbes wrote that international politics provided the best illustration of the anarchical state of nature because it resembled a posture of war of every state against every state.

As we shall see, the assumption that the state is the principal actor, coupled with the view that international politics takes place under a condition of anarchy, helps to 
define the essential core of realism. There is, however, one issue in particular that theorists associated with raison d'état, and classical realism more generally, were concerned with; the role, if any, that morals and ethics occupy in international politics. Realists are skeptical of the idea that universal moral principles exist and, therefore, warn state leaders against sacrificing their own self-interests in order to adhere to some indeterminate notion of "ethical" conduct. Moreover, realists argue that the need for survival requires state leaders to distance themselves from traditional notions of morality. Machiavelli argued that these principles were positively harmful if adhered to by state leaders. It was imperative that state leaders learned a different kind of morality, which accorded not with traditional Christian virtues but with political necessity and prudence. Proponents of raison d'état often speak of a dual moral standard: one moral standard for individual citizens living inside the state and a different standard for the state in its external relations with other states. But before the conclusion that realism is completely immoral is reached, it is important to add that proponents of raison d'état argue that the state itself represents a moral force, for it is the existence of the state that creates the possibility for an ethical political community to exist.

Whether or not contemporary realists, most of whom are university professors, are part of the same continuous tradition that we assume Thucydides, Machiavelli, and Hobbes belong to is a contentious question. In part, it depends on the criteria that is used to define a tradition.

No matter when we date the official beginnings of the field of IR, there is no doubt that Hans J. Morgenthau, who, like many others, fled Nazi Germany and emigrated to the United States during the 1940s, was the most influential realist of the twentieth century. His book, Politics Among Nations: The Struggle for Power and Peace (1948) was the first systematic attempt to create a realist theory of international relations. Theory was necessary for Morgenthau, because without it there was no way to distinguish the subject matter of international politics. Ontologically, politics among nations, for Morgenthau, was a never-ending struggle for power. The key concept for Morgenthau was interest defined in terms of power. All states have interests, but they can only be pursued relative to the amount of power a state possesses. For Morgenthau, the pursuit of the national interest in a world of competing interests was the essence of foreign policy.

Morgenthau provided a theoretical explanation for the ubiquitous struggle for power: human nature. According to Morgenthau, "man is a political animal by nature" who "is born to seek power" (1946, p. 168). He then transfers the bedrock assumption of man's inherent lust for power to describe the behavior of states. Just like individuals, Morgenthau argued that the goal of every state was to maximize power to the optimal level. Methodologically, by assigning primacy to individuals, Morgenthau embraced empiricist-inductivism (Tellis 1995). Beginning with empirical observations about the behavior of individuals and states, Morgenthau aimed to discern universal principles of international politics. Yet, at the same time, Morgenthau was critical of the project to create a science of politics. Like many others of his time, science was viewed as synonymous with positivism, which Morgenthau sharply critiqued in Scientific Man Versus Power Politics (1946). At one point in 
time, positivism was the reigning philosophy of science that rested on three principles: one, a belief that there was a hierarchy of science with the natural sciences being on top; two, there is a unity of science meaning that the basic principles and methods of science were the same; and finally, that scientific knowledge was based on its mode of acquisition - logical empiricism. Theories were viewed instrumentally as a means of uncovering empirical facts. This was widely believed to be the way that the natural sciences produced valid knowledge. Yet, at the end of the day, international politics, for Morgenthau, was more of an art than a science. According to Morgenthau, "the principles of scientific reason are always simple, consistent, and abstract; the social world is always complicated, incongruous and concrete" (1946, p. 10). Power, for example, which encompassed both tangible and non-tangible elements, could never be measured in the same way that physicists measured atmospheric pressure.

The next important development in realist theory was the publication of Kenneth Waltz's seminal Theory of International Politics (1979) that established a new form of structural realism or neorealism. Waltz was critical of all the previous inductive attempts to create a theory of international politics. He termed theories that either focused on human nature or the behavior of individual states as "reductionist." Common to these theories, including Morgenthau's theory, was the idea that the "whole shall be known through the study of its parts" (Waltz 1979, p. 19). Waltz concluded that the inductivist path to theory was a dead end because by only focusing on various pieces of data or specific facts no understanding of how they are connected or how they contribute to certain patterns of behavior is possible. He, therefore, set out to develop a systemic theory that could explain important international outcomes such as wars and the balance of power without any reference to human nature or the political characteristics of specific states. In this manner - and as the section on structural realism unfolds in detail below - Waltz believed that the continuities of international politics could be explained in terms of a similar set of incentives and disincentives that all states confronted.

Methodologically, Waltz pursued a deductive path where the behavior of states was derived from the elements that defined the structure of the international system. Waltz was less interested in explaining the foreign policy behavior of states per se than of important international outcomes such as the balance of power. The international system, according to Waltz, consisted of a structure and interacting units. Ontologically, the structure of the international system was anarchy; international politics took place in the absence of a centralized authority; there is no world government. For Waltz, the anarchical structure of international politics is the permissive cause of war because there really is nothing to prevent one state from attacking another state. The units, according to Waltz, are states and the number of Great Powers at any one time helped to distinguish one structure from another. While the anarchical structure of international politics has been stable for centuries, the distribution of power among the units is more in flux. At the time that Waltz was writing, the distribution of capabilities was characterized by bipolarity: two Great Powers, the United States and the Soviet Union, which was different from previous multi-polar systems. Waltz drew heavily from micro-economic theory to illustrate 
how markets, as well as international systems, are spontaneously generated through the inadvertent actions of firms and states. Yet, once created, the structure greatly shapes the behavior of the units. Waltz argued that there was a strong incentive for states to emulate the behavior of the most successful states, which he claimed were those that sought an appropriate amount of power to maintain their security and existence.

Although Waltz set out to create a systemic theory of international politics, epistemologically he remained wedded to a quasi-positivist, instrumentalist notion of theory. This is most evident in the role that assumptions, such as rationality, play in Waltz's theory. Consistent with instrumental-empiricists, Waltz does not consider theoretical assumptions to be necessarily true, but rather to be useful in the process of creating a theory. Theoretical assumptions, as well as theories themselves, are not, according to instrumental empiricism, intended to mirror reality, but instead to be useful for understanding a specified realm of behavior. But as the positivist conception of science has been thoroughly critiqued by most philosophers of science, other structural realists, such as John J. Mearsheimer, have come to embrace a different epistemological position termed scientific realism. Unlike instrumental-empiricists, scientific realists argue that theories are meant to uncover reality and therefore should be based on assumptions that are real rather than useful (MacDonald 2003). As Mearsheimer writes, "sound theories are based on sound assumptions" (Mearsheimer 2001, p. 30). For Mearsheimer, the assumption that great powers are rational actors is based on the fact that states usually behave rationally because it gives them the best chance to survive. By embracing scientific-realism, Mearsheimer's theory of offensive realism will encounter anomalies when a state does not act rationally whereas non-rational behavior is not a problem for Waltz's theory (Mearsheimer 2009).

Although, as the next section will demonstrate, there are a number of distinct theories of realism, there are, nevertheless, a set of core elements that define the essence of realism. Tim Dunne and Brian Schmidt argue that realists subscribe to the following "three Ss": statism, survival, and self-help. Before discussing each of the three Ss, I begin with the realist assumption that states are rational actors (Dunne and Schmidt 2020).

\section{Rationality}

Although some controversy exists, it clearly is the case that realist theory embraces the assumption of rationality. In fact, it is difficult to envision realist theory without the rational actor assumption. More often than not, the rational actor assumption of realism implies nothing more than the idea that states behave in an instrumental manner to achieve their desired goals. Realists generally do not devote much attention to unpacking the rational actor assumption apart from asserting that states make considered assessments about their external environments and act strategically to realize their interests. As Joseph Grieco (1997, pp. 164-165) explains "state rationality, from a realist viewpoint, has at least three elements." First, "realists 
assume that states are goal oriented." Second, "realists assume that states have consistent goals. . state preferences are ordered and transitive in the sense that if outcome A is preferred to B, and B is preferred to C, then A is preferred to C." Third, "states are assumed by realists to devise strategies to achieve their goals" and "these strategies take into account the rank ordering by states of these goals." It is important to emphasize that although the rational actor assumption is a core element of realist theory, realists themselves acknowledge that states often fail to act in a consistently rational manner. The decision the United States made to invade Iraq in 2003 serves as a recent example of a state behaving in a non-rational manner. For Mearsheimer and Walt (2003), the Iraq War was completely unnecessary because there were other rational options, such as containment, that would have better served American interests.

\section{Statism}

Although there is a plethora of different actors in international politics, such as international organizations (IO's), non-governmental organizations (NGO's) and terrorist groups, realists identify states, and especially the great powers, as the main actors. This is often referred to as the state-centric assumption of realism. For realists, the state is the main actor and sovereignty is its distinguishing characteristic. Sovereignty, in principle, allows each state to determine its own fate and conduct its domestic affairs without any outside interference. Sovereignty means that each state has supreme authority to make and enforce laws within its own territorial space. As the universal pretensions of the Middle Ages, most notably in the form of the Holy Roman Empire, began to wane, the sovereign state slowly began to dominate the political landscape. The formal beginning of the territorial sovereign state system is usually attributed to the Peace of Westphalia (1648), which attempted to resolve the religious tensions between Catholics and Protestants that fueled the destructive Thirty Years' War (1618-1648). By embracing Jean Bodin's (1530-1595) conceptualization of sovereignty, the Peace of Westphalia established two enduring features of international politics: one, that inside the territorial state there is supreme authority to rule; and two, there is no higher power to rule above the separate and distinct states (Knutsen 1992). From the outset, groups of like-minded people, i.e., powerholders, quickly learned that those who organized themselves in the form of a sovereign state had distinct advantages over those who did not. This has been especially the case both in terms of the military capacity to defend one's own state and the ability to wage war against others. As the historical sociologist Charles Tilly (1990) explains, war made the state and the state made war. In terms of military capabilities, sovereign states have had a distinct advantage compared to alternative forms of political organization.

Realist theory operates according to the view that, domestically, the problem of law and order is largely solved. However, on the outside, in the external relations among independent sovereign states, insecurities, dangers, and threats to the very existence of the state loom large. Realists attempt to explain this on the basis that the 
very condition for order and security - namely, the existence of an over-arching centralized authority - is missing from the international realm. This gives rise to the ontological claim that international politics takes place under a condition of anarchy. Realists argue that, in a condition of anarchy, states compete with each other for power and security. Power is viewed as the best means to achieving security. The nature of the competition is frequently viewed in zero-sum terms; in other words, more power for one actor means less for another. This mindset shaped the military policies and alliances of the United States and the Soviet Union throughout the Cold War from 1945-1991. Any gain by one side in terms of nuclear weapons or alliance partners was viewed by the other side as a loss. The competitive logic of power politics makes every state, especially the Great Powers, be attentive to the relative distribution of power. For realists, the aggregate power that a specific state possesses is of lesser importance than where a state stands relative to the power of other states.

As mentioned in the Introduction, realism is often viewed as being synonymous with power politics. Hans J. Morgenthau famously wrote "international politics, like all politics, is a struggle for power" ([1948] 1955, p. 25). Yet this begs the question of how realists understand the concept of power. Stephen Walt, a highly regarded American realist at Harvard University, admits that "the concept of power is central to realist theory, yet there is still little agreement on how it should be conceived and measured" (Walt 2002, p. 222). As the next section will detail, there are differences in how the various schools of realism conceptualize power. In general, however, realists are reluctant to view power in relational terms and instead endorse a national power approach. Proponents of the elements of national power approach equate power with the possession of specific resources. The resources that are most typically used as an indicator of national power include the level of military expenditure, size of the armed forces, gross national product, size of territory and population. Stefano Guzzini (1998) refers to this as the "lump concept of power which assumes that all elements of power can be combined into one general indicator" (2000, p. 55). One of the shortcomings of the national power approach is the difficulty of converting power in terms of resources to the ability to change the behavior of other actors. The Vietnam War (1954-1975), for example, is an interesting case because the United States clearly had overwhelming military capabilities but could not manage to change the behavior of the North Vietnamese who were committed to the unification of Vietnam regardless of the costs.

\section{Survival}

The third principle that unites realists is the assertion that, in world politics, the pre-eminent goal of every state is survival. It is largely on the basis of how realists depict the international environment that they conclude that the first priority for state and military leaders is to ensure the survival of their state. Survival is held to be a precondition for attaining all other goals, whether these involve conquest of others or merely independence. Under anarchy, the survival of the state cannot be guaranteed. As evidenced by history, perhaps no better than the case of Poland during World War 
Two, survival as a political entity is not guaranteed. One reason for this is that unlike the situation domestically, there is no emergency number a state can call when it feels threatened. Another reason is partly explained in terms of the power differentials of states. Intuitively, states with more power stand a better chance of surviving than states with less power. Power is crucial to the realist lexicon and has traditionally been defined narrowly in military strategic terms. Yet irrespective of how much power a state may possess, the core national interest of all states must be survival. Like the pursuit of power, the promotion of the national interest is, according to realists, an iron law of necessity.

What options do states have to ensure their own survival? This brings us to one of the crucial mechanisms that realists throughout the ages have considered essential to preserving the liberty of states - the balance of power. Although various meanings have been attributed to the concept of the balance of power, the most common definition holds that if the survival of a state is threatened by a hegemonic state or coalition of stronger states, they should join forces, establish a formal alliance, and seek to preserve their own independence by checking the power of the opposing side. A classic example of this was the actions taken by the United Kingdom, Austria, Russia and Prussia during the early 1800s to counter France's bid under Napoleon to dominate all of Europe. The mechanism of the balance of power seeks to ensure an equilibrium of power in which no state, or coalition of states, is in a position to dominate all the others. Realists argue that great power war is less likely when there is a relatively equal distribution of power because rational states will only choose war when they believe they will be victorious. The Cold War competition between the East and West, as institutionalized through the formal alliance system of the Warsaw Pact and the North Atlantic Treaty Organization (NATO), provides a prominent example of the balance of power mechanism in action. One way to prevent a hot war between the United States and the Soviet Union was to maintain a balance of power. As the Cold War progressed, each of the two adversaries engaged in an intensive arms race, most noticeable in the quantitative and qualitative increase in nuclear weapons, to ensure that no state gained a power advantage over the other. Following the collapse of the Soviet Union in 1991, there has been a significant imbalance of power. Balance-of-power realists consider this to be a dangerous situation and anticipate a new balance forming whereas certain realists have argued that the presence of a dominant hegemonic power has a pacifying effect (Gilpin 1981).

\section{Self-Help}

In the international system, there is no authority above states to counter the use of force. War is always a possibility because there is nothing that can prevent a state from using force against another state. Security can therefore only be realized through self-help. Waltz (1979, p. 111) explains that in an anarchic structure, "selfhelp is necessarily the principle of action." States must ultimately rely on themselves to achieve security. While states do have the option of joining or forming an alliance, 
there is always the worry that alliance partners may not honor their commitments when they are needed most, as when Italy withdrew from its alliance with the Central Powers at the outset of World War One. In the same vein, throughout the cold war, some states, such as France, questioned whether the United States would risk thermonuclear war with the Soviet Union in order to come to the defense of a NATO member. Because realists insist that international politics is a self-help world, those states that can rely on themselves for security are at a distinct advantage over those who cannot.

Yet in the course of providing for one's own security, the state in question will automatically be fueling the insecurity of other states. The term given to this spiral of insecurity is the security dilemma. According to Wheeler and Booth, security dilemmas exist "when the military preparations of one state create an unresolvable uncertainty in the mind of another as to whether those preparations are for "defensive" purposes only (to enhance its security in an uncertain world) or whether they are for offensive purposes (to change the status quo to its advantage)" (1992, p. 30). This scenario suggests that one state's quest for security is often another state's source of insecurity. States find it difficult to trust one another and are often suspicious of other states' intentions. Thus, the military preparations of one state are likely to be matched by those of neighboring states. According to John Hertz, who was one of the first realists to articulate the security dilemma, "since none can ever feel entirely secure in a world of competing units, power competition ensues, and the vicious circle of security and power competition is on" (1950, p. 157). The irony is that, at the end of the day, states often feel no more secure than before they undertook measures to enhance their own security. Some have suggested that one way to dampen the security dilemma is for states to have a military doctrine that is able to clearly distinguish between offense and defense. The argument is that if states are able to adopt a defensive military posture, conquest would be less likely compared to a situation when offense has the advantage (Jervis 1978). Yet throughout history, it has been difficult to determine whether a particular weapon or military doctrine is inherently offensive or defensive in nature.

\section{One Realism, or Many?}

The notion that there is a monolithic theory of realism is increasingly rejected by those who are both sympathetic to, and critical of, the realist tradition. The alternative view is that there are a number of different realist theories of international politics. In this section, the distinction between classical and structural realism is emphasized. But here, a further distinction is made between Waltzian structural realism and Mearsheimer's structural theory of offensive realism. 


\section{Classical Realism}

The classical realist lineage begins in Ancient Greece with Thucydides' representation of power politics as a law of human behavior. The drive for power and the will to dominate are held to be fundamental aspects of human nature. The behavior of the state as a self-seeking egoist is understood to be a reflection of the characteristics of human beings. It is human nature that explains why international politics is struggle for power. The reduction of realism to a condition of human nature is prominent among classical realists including, Morgenthau. Some have suggested using the label of "human nature realism" instead of classical realism (Mearsheimer 2001). In any event, classical realists argue that it is from the nature of man that the essential features of international politics, such as competition, fear, and war, can be explained. For both Thucydides and Morgenthau, the essential continuity of the power-seeking behavior of states is rooted in the biological drives of human beings.

According to Morgenthau, human nature displays a natural inclination to seek power over others. Realists draw on a number of classical thinkers in the history of political thought, such as Machiavelli and Hobbes, to support the view that human nature explains the ubiquitous struggle for power. Morgenthau likened the three basic patterns of the struggle for power among states - to keep power (status quo), to increase power (imperialism), and to demonstrate power (prestige) - to man's lust for power. The important task of foreign policy was the ability to discern these different patterns and select the most rational policy to ensure the power and survival of one's own state. Morgenthau's theory of realism was meant to provide a rational map of international politics. The central concept for Morgenthau was interest defined in terms of power. He spent the majority of his career trying to persuade American foreign policy officials to follow their own particular national interest.

\section{Structural Realism}

Structural realists concur that international politics is a struggle for power, but they do not attribute this to human nature. Instead, structural realists ascribe security competition and inter-state conflict to the lack of an overarching authority above states. Waltz defined the structure of the international system in terms of three elements - organizing principle, differentiation of units, and distribution of capabilities. The organizing principle, according to Waltz, is anarchy; international politics takes place in the absence of a centralized authority. The units, as we have seen, are states. The only element that fluctuates is the distribution of capabilities among the great powers. According to structural realists, the relative distribution of power in the international system is the key independent variable in understanding important international outcomes such as war and peace, alliance politics, and the balance of power. Structural realists are interested in providing a rank-ordering of states so that they can discern the number of great powers that exist at any particular point in time. The number of great powers, in turn, determines the overall structure of the international system. For example, during the cold war there were two great powers - the 
USA and the Soviet Union - that constituted the bipolar international system, and since the end of the cold war the international system has been unipolar.

How does the international distribution of power impact the behavior of states? In the most general sense, Waltz argues that states, especially the great powers, have to be sensitive to the capabilities of other states. The possibility that any state may use force to advance its interests results in all states being worried about their survival. According to Waltz, power, particularly military power, is a means to the end of security. In a significant passage, Waltz writes "because power is a possibly useful means, sensible statesmen try to have an appropriate amount of it." He adds, "in crucial situations, however, the ultimate concern of states is not for power but for security" (Waltz 1989, p. 40). In other words, rather than being power maximizers, states, according to Waltz, are security maximizers. Waltz argues that power maximization often proves to be suboptimal because it automatically triggers a counterbalancing coalition of states. Like Morgenthau, Waltz believed in the efficacy of the balance of power. Unlike Morgenthau, Waltz argued that achieving a balance of power was easier when the system was bipolar rather than multipolar.

A different account of the power dynamics that operate in the anarchic system is provided by Mearsheimer's theory of offensive realism, which is another variant of structural realism (Mearsheimer 2001). While sharing many of the same basic assumptions of Waltz's structural realist theory, Mearsheimer provides a different and more tragic view of international politics. The environment that states inhabit, according to Mearsheimer, is indeed tragic in that although no one intentionally designed it, there is no way to escape the behavior that all states are compelled to follow, even when such behavior has adverse consequences. Unlike Waltz's description of states as security maximizers, Mearsheimer argues that states are power maximizers. According to Mearsheimer, the structure of the international system compels states to maximize their relative power position. Under anarchy, Mearsheimer agrees that self-help is the basic principle of action, but he argues that states can never be certain about the intentions of other states. Consequently, he concludes that all states are continuously searching for opportunities to gain power at the expense of others.

Mearsheimer is very specific that military power, especially land power, is the quintessence of state power. He argues that a state with the most powerful army is ipso facto the most powerful state. Under anarchy, the accumulation of power is the best route to achieving security. Indeed, the ideal position, although one that Mearsheimer argues is virtually impossible to achieve because of what he calls "the stopping power of water," is to be the global hegemon of the international system. Yet because global hegemony is impossible, he concludes that the world is condemned to perpetual great power competition. 


\section{Conclusion}

Realists believe that realism provides timeless insights about international politics. While critics strongly disagree, realists insist that the power dynamics that are underway today, particularly those related to the rise of China, once again confirm the timeless quality of realism. The character of the power struggle unfolding today between a declining United States and a rising China is eerily similar to the struggle between Athens and Sparta that ultimately resulted in the Peloponnesian War. Thucydides' explanation that the underlying cause of the war was the result of the growth of Athenian power and the fear which this caused in Sparta is a classic example of the impact that the distribution of power has on the behavior of state actors. If we are indeed witnessing a significant change in the distribution of power, the crucial question is whether this can be achieved peacefully and avoid the type of great power war that Thucydides described between Athens and Sparta. While some believed, or hoped, that the American unipolar order could last forever, realists strongly disagreed because they understood that states would eventually seek to check American power. They also understood that countries such as China and Russia would never feel secure in a world in which there is only one dominant power. One of the biggest questions of the early twenty-first century is whether countries such as China and Russia can rise peacefully and usher in a new multipolar international system. While there are a number of different positions on this question, it should be evident by now that realism provides the most appropriate theory for understanding the power dynamics of international politics both in the past and present.

\section{Cross-References}

Rønnfeldt, C. International Relations Theory and Military Sciences

Silverstone, S. Liberal International Relations Theory and the Military

Agius, C. Social Constructivist International Relations and the Military

- Baumann, M. Poststructuralism in International Relations: Discourse and the Military

\section{References}

Allison, G. (2018). Destined for war: Can America and China escape the Thucydides's trap? New York: Mariner Books.

Bew, J. (2016). Realpolik: A history. Oxford: Oxford University Press.

Carr, E. H. (1939/1964). The twenty years' crisis, 1919-1939: An introduction to the study of international relations. New York: Harper \& Row.

Dunne, T., \& Schmidt, B. C. (2020). Realism. In J. Baylis, S. Smith, \& P. Owens (Eds.), The globalization of world politics (pp. 130-144). Oxford: Oxford University Press.

Gilpin, R. (1981). War and change in world politics. New York: Cambridge University Press.

Gilpin, R. (1996). No one loves a political realist. Security Studies, 5(3), 3-28. 
Grieco, J. (1997). Realist international theory and the study of world politics. In M. Doyle \& G. John Ikenberry (Eds.), New thinking in international relations theory (pp. 163-201). Boulder: Westview Press.

Guzzini, S. (1998). Realism in international relations and political economy: The continuing story of a death foretold. London: Routledge.

Guzzini, S. (2000). The Use and Misuse of Power Analysis in International Theory. In Ronen Palan ed., Global Political Economy: Contemporary Theories. London: Routledge.

Hertz, J. (1950). Idealist internationalism and the security dilemma. World Politics, 2, 157-180.

Hobbes, T. (1968). In C. B. Macpherson (Ed.), Leviathan. New York: Penguin Books.

Jervis, R. (1978). Cooperation under the security dilemma. World Politics, 30, 167-214.

Knutsen, T. (1992). A history of international relations theory. Manchester: Manchester University Press.

MacDonald, P. (2003). Useful fiction or miracle maker: The competing epistemological foundations of rational choice theory. American Political Science Review, 97(4), 551-565.

Mearsheimer, J. (2001). The tragedy of great power politics. New York: W.W. Norton \& Company.

Mearsheimer, J. (2009). Reckless states and realism. International Relations, 23, 241-256.

Mearsheimer, J., \& Walt, S. (2003). An Unnecessary War. Foreign Policy, 134, 50-59.

Meinecke, F. (1957). Machiavellism: The doctrine of "Raison d'Etat" and its place in modern history (D. Scott, Trans.). London: Routledge.

Morgenthau, H. J. (1946). Scientific man versus power politics. Chicago: University of Chicago Press.

Morgenthau, H. J. (1948/1954). Politics among nations: The struggle for power and peace (2nd ed.). Chicago: University of Chicago Press.

Schmidt, B. C. (Ed.). (2012). International relations and the first great debate. London: Routledge.

Tellis, A. (1995). Reconstructing political realism: The long march to scientific theory. Security Studies, 5(2), 3-94.

Tilly, C. (1990). Coercion, capital, and European states, AD 990-1990. Oxford: Blackwell.

Walt, S. (2002). The enduring relevance of the realist tradition. In I. Katznelson \& H. V. Milner (Eds.), Political science: The state of the discipline (pp. 199-230). New York: W.W. Norton.

Waltz, K. (1989). The origins of war in neorealist theory. In R. Rotberg \& T. Rabb (Eds.), The origin and prevention of major wars (pp. 39-52). Cambridge: Cambridge University Press. 
Wheeler, N., \& Booth, K. (1992). The security dilemma. In J. Baylis \& N. Rengger (Eds.), Dilemmas of world politics: International issues in a changing world (pp. 29-60). Oxford: Oxford University Press.

\section{Further Reading}

\section{For a General Survey of the Realist Tradition}

Guzzini, S. (1998). Realism in international relations and international political economy. London: Routledge.

Smith, M. J. (1986). Realist thought from weber to Kissinger. Baton Rouge: Louisiana State University Press.

Williams, M. C. (2005). The realist tradition and the limits of international relations. Cambridge: Cambridge University Press.

\section{Classical Realism}

Morgenthau, H. J. (1948/1952). Politics among nations: The struggle for power and peace. New York: Alfred A. Knopf.

Thucydides. (1954/1972). The Peloponnesian war (R. Warner, Trans.). London: Penguin.

\section{Structural Realism}

Mearsheimer, J. (2001). The tragedy of great power politics. New York: W. W. Norton. Waltz, K. (1979). Theory of international politics. Reading: Addison-Wesley.

Open Access This chapter is licensed under the terms of the Creative Commons Attribution 4.0 International License (http://creativecommons.org/licenses/by/4.0/), which permits use, sharing, adaptation, distribution and reproduction in any medium or format, as long as you give appropriate credit to the original author(s) and the source, provide a link to the Creative Commons license and indicate if changes were made.

The images or other third party material in this chapter are included in the chapter's Creative Commons license, unless indicated otherwise in a credit line to the material. If material is not included in the chapter's Creative Commons license and your intended use is not permitted by statutory regulation or exceeds the permitted use, you will need to obtain permission directly from the copyright holder.

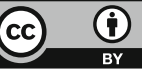

